\title{
The clinical utility of HTLV-1 viral load measurement
}

\author{
Maria A Demontis*, Silva Hilburn, Graham P Taylor \\ From 15th International Conference on Human Retroviruses: HTLV and Related Viruses \\ Leuven and Gembloux, Belgium. 5-8 June 2011
}

\section{Introduction}

High levels of HTLV-1 proviral load in peripheral blood mononuclear cells (PBMCs) have been observed in patients with Adult $\mathrm{T}$-cell Leukaemia Lymphoma (ATLL) and HTLV-1 Associated Myelopathy/Tropical Spastic Paraparesis (HAM/TSP). The proviral load has been reported to fluctuate in both asymptomatic carriers and in symptomatic patients. We aimed to quantify intra-patient variability, to identify "outliers", and to characterise the range of viral loads in asymptomatic carriers and in patients with HTLV-1-associated diseases.

\section{Methods}

Viral loads were quantified using a SYBR Green-based real-time quantitative polymerase chain reaction, and expressed as a percentage of infected PBMCs.

\section{Results}

1. Mean viral loads were significantly different between asymptomatic carriers and HAM/TSP $(\mathrm{p}<0.001)$, and between asymptomatic carriers and ATLL $(\mathrm{p}=0.001)$;

2 . Viral loads below $1 \%$ were found only in asymptomatic carriers;

3. $15 \%$ of asymptomatic carriers had a viral load $>10 \%$, $3 \%>20 \%$;

4. The intra-assay CV increases as viral load decreases;

5. The inter-assay CV at low loads is not different from the intra-assay CV;

6. Mean intra-patient CV is $65 \%$ (SD 21) in asymptomatic carriers, and 51\% (23) in HAM/TSP.

\section{Discussion}

HTLV-1 viral load is highly variable between infected patients. We speculate that asymptomatic carriers with a

\footnotetext{
* Correspondence: m.demontis@imperial.ac.uk

Section of Infectious Diseases, Imperial College, London, W2 1PG, UK
}

viral load higher than $10 \%$ are more likely to develop HTLV-1 associated diseases. We suggest the use of intra-patient variability $(\mathrm{CV})$ to identify significant variations in viral load, that would allow the identification of patients who may be developing an associated disease, or to assess the efficacy of treatments to reduce viral load.

Published: 6 June 2011

doi:10.1186/1742-4690-8-S1-A46

Cite this article as: Demontis et al:: The clinical utility of HTLV-1 viral load measurement. Retrovirology 2011 8(Suppl 1):A46.
Submit your next manuscript to BioMed Central and take full advantage of:

- Convenient online submission

- Thorough peer review

- No space constraints or color figure charges

- Immediate publication on acceptance

- Inclusion in PubMed, CAS, Scopus and Google Scholar

- Research which is freely available for redistribution
C Biomed Central

\section{() Biomed Central}

